\title{
MAML3 Gene
}

National Cancer Institute

\section{Source}

National Cancer Institute. MAML3 Gene. NCI Thesaurus. Code C117094.

This gene plays a role in both transcriptional activation and signaling. 